\title{
Biodegradable films of starch/PVOH/alginate in packaging systems for minimally processed lettuce (Lactuca sativa L.)
}

\author{
Filmes biodegradáveis de amido/PVOH/alginato em sistema de \\ embalagem para alface (Lactuca sativa L.) minimamente processada
}

\author{
Renata Paula Herrera Brandelero ${ }^{1 *}$, Evandro Martin Brandelero', Fábio Mendonça de Almeida
}

'Universidade Tecnológica Federal do Paraná/UTFPR, Dois Vizinhos, PR, Brasil

*Corresponding author: renatapherrera@gmail.com

Received in February 29, 2016 and approved in July 29, 2016

\begin{abstract}
Biodegradable packaging may replace non-biodegradable materials when the shelf life of the packaged product is relatively short, as in minimally processed foods. The objective of this work was to evaluate the efficiency of biodegradable films comprising starch/polyvinyl alcohol (PVOH)/alginate with the addition of 0 or $0.5 \%$ of essential oil of copaiba (EOCP) or lemongrass (EOLM) compared to poly-vinyl chloride (PVC) films in the storage of minimally processed lettuce. Lettuce samples cut into 1-cm strips were placed in polypropylene trays wrapped with biodegradable films and stored at $6 \pm 2{ }^{\circ} \mathrm{C}$ for 8 days. PVC films were used as controls. The biofilms presented 11.43-8.11 MPa resistance and 11.3-13.22\% elongation, with water vapor permeability (WVP) of 0.5-4.04 x 10-12 $\mathrm{g} . \mathrm{s}^{-1} \cdot \mathrm{Pa}^{-1} \cdot \mathrm{m}^{-1}$; thus, the films' properties were considered suitable for the application. The lettuce stored in PVC presented minor total soluble solids (TSS), less luminosity (L), higher intensity of yellow color (b), and eight times less mass loss than that stored in biodegradable films. Multivariate analysis showed that the lettuce lost quality after 2 days of storage in PVC films, representing a different result from the other treatments. Lettuce stored in biodegradable films for 2 and 4 days showed a greater similarity with newly harvested lettuce (time zero). The films with or without the addition of essential oil showed similar characteristics. Biodegradable films were considered viable for the storage of minimally processed lettuce.
\end{abstract}

Index terms: Active packaging; biopolymer; copaiba oil; lemongrass oil.

\section{RESUMO}

As embalagens biodegradáveis podem substituir as não biodegradáveis quando a vida de prateleira do produto embalado é relativamente curta, como no caso dos alimentos minimamente processados. Neste trabalho o objetivo foi avaliar a eficiência de filmes biodegradáveis de amido/PVOH/alginato adicionados de 0 ou 0,5\% de óleo essencial de copaíba (EOCP) ou de capim limão (EOLM) em comparação aos filmes de PVC ao longo do armazenamento de alfaces minimamente processadas. As alfaces cortadas em tiras de $1 \mathrm{~cm}$ foram dispostas em bandejas de polipropileno armazenadas a $6 \pm 2{ }^{\circ} \mathrm{C}$ por 8 dias. Filmes de PVC foram utilizados como controle. Os biofilmes apresentaram 11,43-8,11 MPa de resistência, 11,3-13,22\% de elongação e permeabilidade ao vapor de água (PVA) entre $0,5-4,04 \times 10^{-12} \mathrm{~g} \cdot \mathrm{s}^{-1} \cdot \mathrm{Pa}^{-1} \cdot \mathrm{m}^{-1}$, sendo os filmes biodegradáveis considerados adequados á aplicação devido as propriedades apresentadas. As alfaces armazenadas em PVC apresentaram queda brusca dos sólidos solúveis totais (SST), menor luminosidade (L), maior intensidade da cor amarela (b) e perda de massa (2\%) oito vezes menor que as armazenadas em filmes biodegradáveis (12-16\%) aos 8 dias de armazenamento. A análise multivariada evidenciou que as alfaces em filmes de PVC perderam qualidade aos 2 dias de armazenamento diferindo dos demais tratamentos. Já alfaces armazenadas em biofilmes por 2 e 4 dias apresentaram maior similaridade com as alfaces recém colhidas (tempo zero). Os filmes biodegradáveis foram considerados viáveis ao armazenamento de alface minimamente processada.

Termos para indexação: Embalagem ativa; biopolímeros; óleo de copaíba; óleo de capim limão.

\section{INTRODUCTION}

Biopolymers present the characteristics of high availability, biodegradability, low cost, and renewability; for these reasons, they are suitable for confection eco-friendly packaging. They may be employed in the manufacture of plastic packaging for short-term use, such as for packaging minimally processed food (Gilbert; Gontard; Gorris, 1996; Lin; Zhao, 2007).

Biodegradable films have been applied in the conservation of green peppers and minimally processed lettuce, respectively, by Koide and Shi (2007) and Marin et al. (2010). These authors observed that the films with starch or polylactate (PLA) increased the conservation of these food. Moreover, the addition of essential oil as 
an antimicrobial can help to improve the performance of biodegradable films in the conservation of food (Fakhouri et al., 2007). Debiagi et al. (2014) verified that the addition of antimicrobials, such as essential oil of clove or oregano, diminished the yeast, mold, and bacterial counts in starch films. In accordance with these authors, it can be stated that starch films with the addition of antimicrobial agents have advantages over non-biodegradable plastic films, as they reduce the rate of growth of specific microorganisms.

When added to packaging films, antimicrobials are released in a controlled manner on the surface of the food to inhibit the proliferation of microorganisms; in this way, the amounts of antimicrobials needed for microbiological control are much smaller than when the antimicrobial agents are incorporated into the products themselves, thereby supporting the trend of reduced additives in foods (Ghasemlou et al., 2013). The incorporation of essential oils in films and not in the formulation can diminish alterations in food in terms of taste and odor (Burt, 2004).

A major component of the lemongrass oil is citral, a substance with recognized fungitoxic properties (Guimarães et al., 2011). The essential copaiba oil is extracted from a native tree from the Amazon forest, and it is frequently used by the natives of this region as a medicinal product; it consists of a mixture of diterpenes and sesquiterpenes with antifungal activity (Pieri; Mussi; Moreira, 2009).

Starch films exhibit low permeability to oxygen and carbon dioxide gas, which is an important property in the conservation of fruits and vegetables that are engaged in the processes of oxidative respiration after harvesting (Falguera et al., 2011; Lin; Zhao, 2007; Mali et al., 2010; Soliva-Fortuny; Martin-Belloso, 2003). Meanwhile the high hydrophilicity of films from starch allows exchanges of moisture between food and the environment, and the water absorbed in starch films acts as plasticizer that makes the films weak and sticky; this limits the applications of starch films in packaging systems for foods (Mali et al., 2010).

The mixing of starch with polyvinyl alcohol (PVOH) and alginate (ALG) was studied by Brandelero et al. (2014), and the quantities of each polymer were optimized to improve the mechanical properties and decrease the hydrophilicity of the material. The authors observed that the ternary mixture of polymers resulted in films that were more resistant to tension, less permeable to water vapor, and less hydrophilic than films containing only starch. This effect was due to the reduction in availability of sites in connection with the water vapor caused by the increased interactions between polymeric chains (Brandelero et al., 2014; Córdaba et al., 2008).

The objective of this work was to evaluate the efficiency of starch/PVOH/alginate films with and without the addition of essential oil in the development of microorganisms and in the physicochemical characteristics of minimally processed lettuce during the refrigerated storage.

\section{MATERIAL AND METHODS}

The films were prepared with cassava starch purchased from the Pinduca Food Industry located in the city of Araruna, (Brazil), polyvinyl alcohol (PVOH) was obtained of Sekisui Chemical Co. (E523) with a degree of hydrolysis of $89 \%$, and sodium alginate (ALG) Algin I-3G, medium viscosity, was acquired from the Chemical Corporation (Chile). Commercial-grade glycerol with $98 \%$ purity was purchased (Emfal, Brazil). Essential oils from copaiba (Copaifera reticulata DucKe) and lemongrass (Cymbopogon citratus) were acquired from Florananda Industry and Commerce of Natural Products Ltda (Brazil), containing $100 \%$ essential oil extracted from lemongrass leaves and the resin obtained from Copaifera trees.

\section{Production of films}

The films were produced by the casting method with a ternary mixture of thermoplastic starch (ATP), PVOH, and ALG. Table 1 presents the formulations of the films. The films were prepared by adding $4 \mathrm{~g}$ of polymers to $100 \mathrm{ml}$ of the solution, and the total values of the film composition were $3.2 \mathrm{~g}$ of starch $(80 \%$ of the mass of the polymer), $0.344 \mathrm{~g} \mathrm{PVOH}$ (8.6\% of the mass of the polymer), and $0.456 \mathrm{~g}$ alginate $(11.4 \%$ of the mass of polymers). Following this, $0.5 \mathrm{~g}$ essential oil of lemongrass (EOLM) or essential oil of copaiba (EOCP) was added to $100 \mathrm{ml}$ of the filmogenic solution. Twenty percent glycerol calculated from the mass of polymers was added to all films. Films without essential oil obtained using the same proportions of polymers (WEO) served as a control.

The starch was gelatinized in the presence of glycerol with agitation to $70{ }^{\circ} \mathrm{C}$ for 45 minutes. A solution containing PVOH/ALG was heated to $80{ }^{\circ} \mathrm{C}$ until a viscous and homogeneous solution was formed. The starch solution with glycerol was added to the PVOH/ALG solution to produce the blends. After the two solutions were combined, the resulting mixture was heated to $80^{\circ} \mathrm{C}$ under moderate agitation for 15 minutes, and solution for the films was obtained. 
Table 1: Formulation of the films applied in the conservation of minimally processed lettuce.

\begin{tabular}{cccccc}
\hline Treatment & $\begin{array}{c}\text { Starch (g/100 } \\
\text { ml solution) }\end{array}$ & $\begin{array}{c}\mathrm{PVOH}(\mathrm{g} / 100 \\
\text { ml solution) }\end{array}$ & $\begin{array}{c}\text { Alginate (g/100 } \\
\text { ml of solution) }\end{array}$ & $\begin{array}{c}\text { Essential oil (g/100 } \\
\text { ml solution) }\end{array}$ & $\begin{array}{c}\text { Glycerol (g/100 } \\
\text { ml solution) }\end{array}$ \\
\hline WEO & 3.2 & 0.344 & 0.456 & 0.0 & 0.8 \\
EOLM & 3.2 & 0.344 & 0.456 & 0.5 & 0.8 \\
EOCP & 3.2 & 0.344 & 0.456 & 0.5 & 0.8 \\
\hline
\end{tabular}

WEO - films of starch/PVOH/alginate without essential oil, EOLM - films of satrch/PVOH/alginate with essential oil of lemongrass, EOCP - films of starch/PVOH/alginate with essential oil of copaiba.

The essential oil was added to the filmogenic solutions at ambient temperature in quantities of $0.5 \%$ (calculated in relation to the volume of the solution). The solutions were scattered on acrylic boards ( $300 \mathrm{~mm} \times 215$ $\mathrm{mm} \times 10 \mathrm{~mm}$ ) in the fixed quantity of $15 \mathrm{mg}$ of solution/ $\mathrm{cm}^{2}$ to obtain films with a thickness of $0.05 \mathrm{~mm}$. The plates were dried in an oven at $40{ }^{\circ} \mathrm{C}$ for 14 hours.

\section{Minimal processing}

Leaves of crispy lettuce (Lactuca sativa) were acquired in sufficient quantity to perform the experiment in a vegetable-producing property located in the city of Dois Vizinhos, Brazil.. After harvesting the leaves were transported to the laboratory, where they were manually cut into strips of $1 \mathrm{~cm}$ in width after being sanitized in sodium hypochlorite solution at a concentration of $150 \mathrm{mg} \mathrm{L}^{-1}$ for 30 minutes. After the sanitization, the leaves were washed, centrifuged, and dried on paper towel to remove excess water.

The leaves of minimally processed lettuce were placed in trays of polypropylene (PP) that had been previously sanitized with sodium hypochlorite. The containers had a free volume of $200 \mathrm{~cm}^{3}$, and the area of the opening was $100.5 \mathrm{~cm}^{2}$. The trays were covered with biodegradable plastic films with or without the addition of essential oil or PVC films. The quantity of lettuce in each container was approximately $45 \mathrm{~g}$, and each tray held one sample. The experiment was prepared in triplicate. After sealing with the films described in Table 1 , the trays were weighed and chilled to $6 \pm 2{ }^{\circ} \mathrm{C}$ in a refrigerator with an internal moisture of $60 \pm 10 \%$ of relative humidity (RU).

Lettuce samples were analyzed after processing in relation to the parameters of color, total titratable acidity (TTA), total soluble solids (TSS), $\mathrm{pH}$, ascorbic acid content (Ascorbic), and loss of mass (LM). The values were obtained at $0,2,4$, and 8 days of storage. Microbiological examination was carried out. The yeast and mold counts, count of aerobic mesophilic bacteria, and counts of total and fecal coliform were determined in leaves of lettuce stored for 0 and 8 days.

\section{Determination of $\mathrm{pH}$, total titratable acidity (TTA), ascorbic acid (ascorbic), and soluble solids (TSS)}

The analyses of $\mathrm{pH}$, TTA in citric acid, and TSS content were performed according to the Norms of Instituto Adolfo Lutz (1985). The soluble solid content was determined using a digital refractometer, model RTD 45 , while $\mathrm{pH}$ was measured with an Instrutherm digital potentiometer, model 1900. The ASC was determined according to the methodology of Benassi and Antunes (1988). The values were presented in triplicate at time zero and after 2,4 , and 8 days of storage.

\section{Determination of color}

The color was determined using a Minolta colorimeter, Model CR-4110, using the CIE-Lab system. The values of $-a^{*}, b^{*}, C^{*}$, and $\mathrm{L}^{*}$ were obtained in triplicate by the equipment on equal portions of lettuce leaves. Lettuce stored with different film coatings were analyzed at time 0 and after 2, 4, and 8 days of storage.

\section{Microbiological quality}

The counts of molds and yeasts, as well as mesophilic aerobic, total, and fecal coliforms, were performed using Petrifilm 3M plates that were adequate for each specific microbial culture. The preparation and dilution of the samples were carried out following Brazil (2003). The microbiological colony count was performed at time zero and after 8 days of storage.

\section{Loss of mass (LM)}

The LM during storage was determined by weighing the sampling units at $0,2,4$, and 8 days of storage, and the percentage of losses was calculated from the ratio between the mass at each time point and that at time zero. The losses of mass values were adjusted using linear regression. 


\section{Characterization of the films}

\section{Thickness}

The thickness was determined using a manual micrometer (Mitutoyo, Japan). The final thickness was the arithmetic mean of 10 measurements of five random measurements of two samples conditioned for 48 hour at $64 \%$ of $\mathrm{RH}$.

\section{Water vapor permeability (WVP)}

The WVP of films was determined as the gravimetric method adapted from the norm 96-95 of ASTM (ASTM, 1995). (The gradient of $\mathrm{RH}$ remained at $73 \%$ ). The relative humidity (RH) was $2 \%$ at $\mathrm{RH}_{2}$ and $75 \%$ at $\mathrm{RH}_{1}$. The WVP was calculated using Equation 1:

$$
\mathrm{WVP}=\frac{\mathrm{TPVA} \cdot \delta}{\mathrm{A} \cdot \mathrm{P}_{\mathrm{S}} \cdot\left(\frac{\mathrm{RH}_{1}-\mathrm{RH}_{2}}{100}\right)}
$$

where TPVA is the rate of WVP (g water/day), $\delta$ is the average thickness of films ( $\mathrm{m}$ ), $\mathrm{A}$ is the area of permeation of the capsule $\left(28.26 \times 10^{-4} \mathrm{~m}^{2}\right), \mathrm{P}_{\mathrm{s}}$ is the pressure of the saturation of the vapor of water at $25^{\circ} \mathrm{C}(163.678 .8)$, and $\mathrm{RH}$ is the relative humidity inside the desiccator (subindex 1 ) and the dish (subindex 2).

\section{Opacity}

The opacity corresponds to the value of the intensity of light radiation that the films are blocking. The opacity of the films was determined using a Luxmeter (Instrutherm, LM- 8000A). The films were cut to a size of $4 \times 4 \mathrm{~cm}$ and placed over the Luxmeter sensor to measure the intensity of the light crossing through the films. The analysis was carried out in environmental light. The measurements were read in Lux with four repetitions per sample. The opacity was calculated as the percentage of light blocked by films (\%Lux) using the Equation 2:

$\% \operatorname{Lux}=\frac{\operatorname{Lux} i-\operatorname{Lux} f}{\operatorname{Lux} i} \times 100$

where $\operatorname{Lux}_{\mathrm{i}}$ is the measure of the intensity of the Lux of the environment, and $\operatorname{Lux}_{\mathrm{f}}$ is the measurement of the intensity of light crossing the film.

\section{Mechanical properties}

The mechanical properties were found to conform to the standard D 882-02 of ASTM (ASTM, 1996). The maximum resistance to traction and the elongation were analyzed using a Pro Stable Micro System texturometer, model TA.TX2i (England). The dimensions of the specimens were about $50 \times 20 \mathrm{~mm}^{2}$, and the RH was equilibrated to $52.9 \%$. The specimens were placed between pneumatic clamps, with the distance between the grips set to $50 \mathrm{~mm}$ and a speed of traction of $0.83 \mathrm{~mm} / \mathrm{min}$. The tests were carried out in a conditioned room at $25^{\circ} \mathrm{C}$. Four measurements were taken for each sample. The resistance to perforation was measured using $30 \times 30 \mathrm{~mm}^{2}$ specimens. The resistance values were expressed in Newton $/ \mathrm{mm}$, with the values for perforation divided by the thickness of films to standardize the effect of the same in the perforation.

\section{Multivariate analysis}

The results of TSS; ASC; pH; TTA; color parameters $-a^{*}, b^{*}$, and L*; and LM for the different treatments (WEO, EOLM, EOCP, and PVC) at each time point $(0,2,4$ and 8 days) were used in the hierarchical analysis and in the analysis of the main components. The overall matrix with dimensions of $16 \times 24$ was obtained with four treatments (WEO, EOLM, EOCP, and PVC) and four different times $(0,2,4$, and 8 days of storage), with values obtained in triplicate from eight variables (SST, ASC, $\mathrm{pH}, \mathrm{TTA},-\mathrm{a}^{*}$, $b^{*}, L^{*}$, and $\left.L M\right)$. The original values in each column were subtracted from the respective averages and divided by the standard deviation from the normalized data. The Statistic 6.0 program was used for statistical analysis. The graphs of groups, loadings, and scores were obtained to assist in the interpretation of results.

\section{RESULTS AND DISCUSSION}

The biodegradable films were evaluated in comparison with a PVC film. Figure 1 presents the general appearance of the lettuce leaves after 8 days of storage (Figure 1, F1-A at F1-D). Biodegradable films showed no visible changes in appearance; however, it was observed that the leaves that were in contact with the biodegradable films were apparently less turgid than the leaves that were not in contact with the biofilms.

\section{Characteristics of biodegradable films}

The thickness of the biodegradable films was fixed at $50 \mu \mathrm{m}$, and it was determined that the variation in the thickness of the biodegradable films not statistically significant $(p>0.05)$. The PVC films showed minor thickness than the biodegradable films (Table 2). The WVP of PVC film was not evaluated. The values of WVP determined for starch/PVOH/alginate films are shown 
in Table 2. These values were smaller than the values determined by Lin and Zhao (2007) for PVC films, who presented a WVP value equal to $2.6 \times 10^{-11} \mathrm{~g} \cdot \mathrm{s}^{\mathrm{S}} \cdot \mathrm{Pa}^{-1} \cdot \mathrm{m}^{-1}$, indicating that the prepared starch/PVOH/alginate films were 10 times less permeable to water vapor than PVC films on a gradient of $73 \%$ humidity.

It was observed that the starch/PVOH/alginate films formulated with essential oil were more permeable than those without oil. These results indicate that the WVP of the films was more dependent on the process of diffusion than that of solubility of water vapor in the matrix of the film. Brandelero et al. (2014) characterized starch/PVOH/ alginate films with lemongrass or copaiba oils, and they stated that the action of oil on the WVP was related to the formation of relatively large cracks in the matrix of films, which contributed to the process of diffusion of water vapor.

The resistance and the elongation of the films were evaluated (Table 2). The values of resistance were considered characteristic of films of cassava starch supplemented with 20\% glycerol. (Bergo et al., 2008; Mali et al., 2006; Talja et al., 2008). It was observed that values of maximum resistance at rupture (MRR) and elongation at rupture were not significantly different between starch/ PVOH/alginate films with and without oil $(p>0.05)$. The results for mechanical properties obtained for starch/ $\mathrm{PVOH} /$ alginate films indicated that the addition of oil did not hinder the structure of films. These results differ from those of previous authors (Chasemlou et al., 2013; Pelissari et al., 2009; Souza et al., 2013), who observed a reduction in the resistance and an increase in the elongation of starch films containing added essential oils.

The starch/PVOH/alginate films had similar opacity to that of PVC films, indicating that the addition of oil does not diminish the transparency of films. The values of opacity indicated that the starch/PVOH/alginate films presented transparency similar to PVC film. Similar results were obtained by Gallardo-Pérez et al. (2012), who observed no differences in appearance or opacity in starch films with or without the addition of beeswax or sunflower oil.
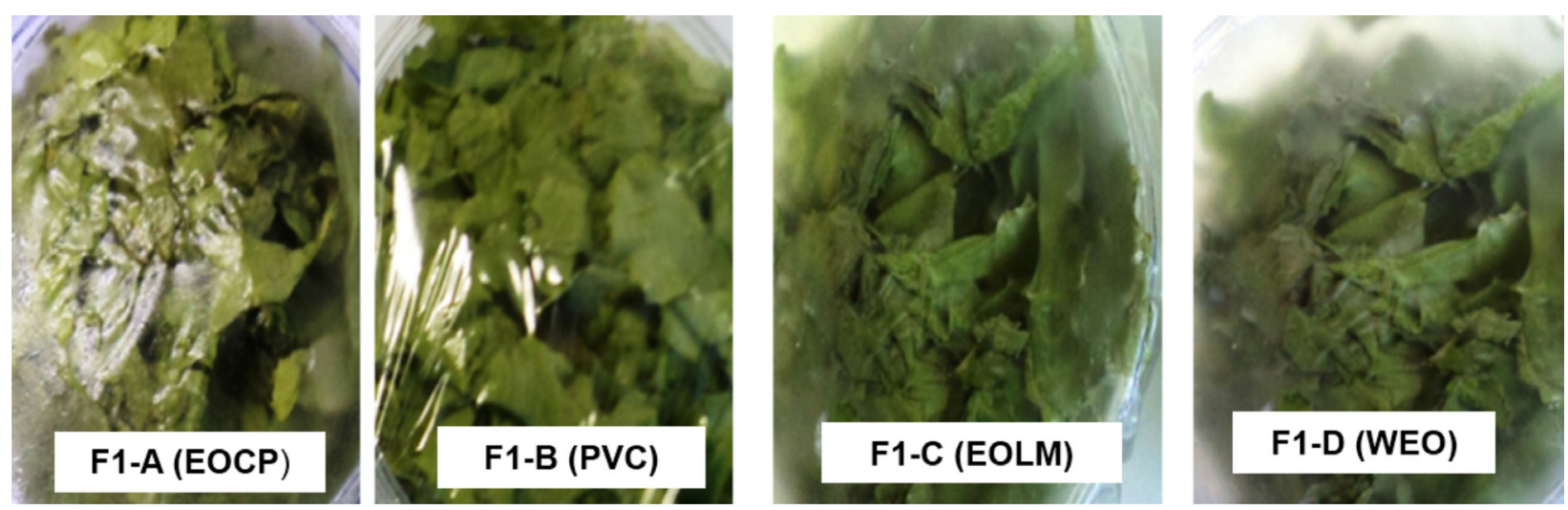

Figure 1: The appearance of the minimally processed lettuce leaves after 8 days of storage in films with essential oil of copaiba (EOCP): F1-A; in PVC films: F1-B; in films with essential oil of lemongrass (EOLM): F1-C; and in films without essential oil (WEO) F1-D.

Table 2: Characterization of the films developed in relation to Water Vapor Permeability (WVP), mechanical properties, opacity, and thickness.

\begin{tabular}{cccccc}
\hline Formulation & $\begin{array}{c}\text { WVP } \\
\left(10^{-12} \mathrm{~g} \mathrm{~s}^{-1} \cdot \mathrm{Pa}^{-1} \cdot \mathrm{m}^{-1}\right)\end{array}$ & $\begin{array}{c}\text { Maximum resistance to } \\
\text { rupture (Mpa) }\end{array}$ & $\begin{array}{c}\text { Elongation at } \\
\text { rupture (\%) }\end{array}$ & $\begin{array}{c}\text { Opacity } \\
(\% \mathrm{Lux})\end{array}$ & $\begin{array}{c}\text { Thickness } \\
(\mathrm{mm})\end{array}$ \\
\hline PVC & - & - & - & 9.80 & $10.0^{\mathrm{b}}$ \\
WEO & $0.50^{\mathrm{c}}$ & 8.11 & 11.3 & 9.25 & $49.4^{\mathrm{a}}$ \\
EOCP & $4.04^{\mathrm{a}}$ & 6.20 & 13.02 & 11.82 & $51.0^{\mathrm{a}}$ \\
EOLM & $2.02^{\mathrm{b}}$ & 11.43 & 13.23 & 9.15 & $64.0^{\mathrm{a}}$ \\
\hline
\end{tabular}

Values followed by the same letters in the columns did not significantly differ according to the Tukey test at 95\% probability. 


\section{Loss of mass (LM)}

The biofilms produced were applied as a coating of trays for the storage of minimally processed lettuce. The LM of lettuce in relation at films was calculated, and the values obtained were adjusted by linear regression. Figure 2 represents the LM of lettuce leaves according to storage time in starch/ $\mathrm{PVOH} /$ alginate films with or without essential oils, as well as that stored in PVC films. It was observed that the starch/ $\mathrm{PVOH} /$ alginate films allowed greater LM than the PVC film. The value for the loss of water was similar in films with and without essential oil, indicating that in the concentration applied, copaiba and lemongrass oil had no effect on the films' barrier properties concerning water vapor. The samples packed with PVC films presented values of mass loss equal to $2 \%$ after 8 days of storage, while samples with biofilm (WEO) presented loss of $14-16 \%$ in the same period.

The RH inside the refrigerator varied from 50 to $70 \%$, and the lettuce leaves were constituted of at least $90 \%$ water; thus, the migration of water vapor from the inside to the outside of the package was favored. The values obtained for the LMs found in this work for lettuce stored in starch/PVOH/alginate films were much lower than those determined by Marin et al. (2010), who reported about $40 \%$ of mass loss of lettuce after 8 days of storage in films composed solely of starch; this indicated that the mixture of starch with alginate and $\mathrm{PVOH}$ improved the performance of starch films in relation to the LM.
The WVP values of starch/PVOH/alginate films (Table 2) were similar to values determined for PVC films by other authors; however, the biodegradable films showed more LM (Figure 2). These results indicated that the values of WVP of starch/PVOH/alginate films probably changed during the time in storage. The contact of starch/ $\mathrm{PVOH} /$ alginate film with the lettuce leaves may have caused retention of water in the matrix of the films, thereby increasing the value of WVP due to the plasticizer effect of water. This is in accordance with Brandelero, Grossmann and Yamashita' (2010) finding that starch films present an increase in the WVP value with increasing RH. This behavior was related to the plasticizing effect of water. In this process, the water retention in the matrix of the film increases the free volume between the polymers chains of the starch and the molecular mobility, while decreasing the crystalline regions of the films; this favors the passage of water vapor, leading to an increase in WVP. These results reinforce the observations in this work, indicating that the WVP is an important factor in controlling the loss of water.

\section{Microbiological stability}

The microbiological stability of minimally processed lettuce was evaluated according to the storage time, as well as the results for mold and yeast, aerobic mesophile, and total and fecal coliform bacterial counts, as presented in Table 3. It was observed that after 8 days of storage, the mold and yeast counts increased significantly

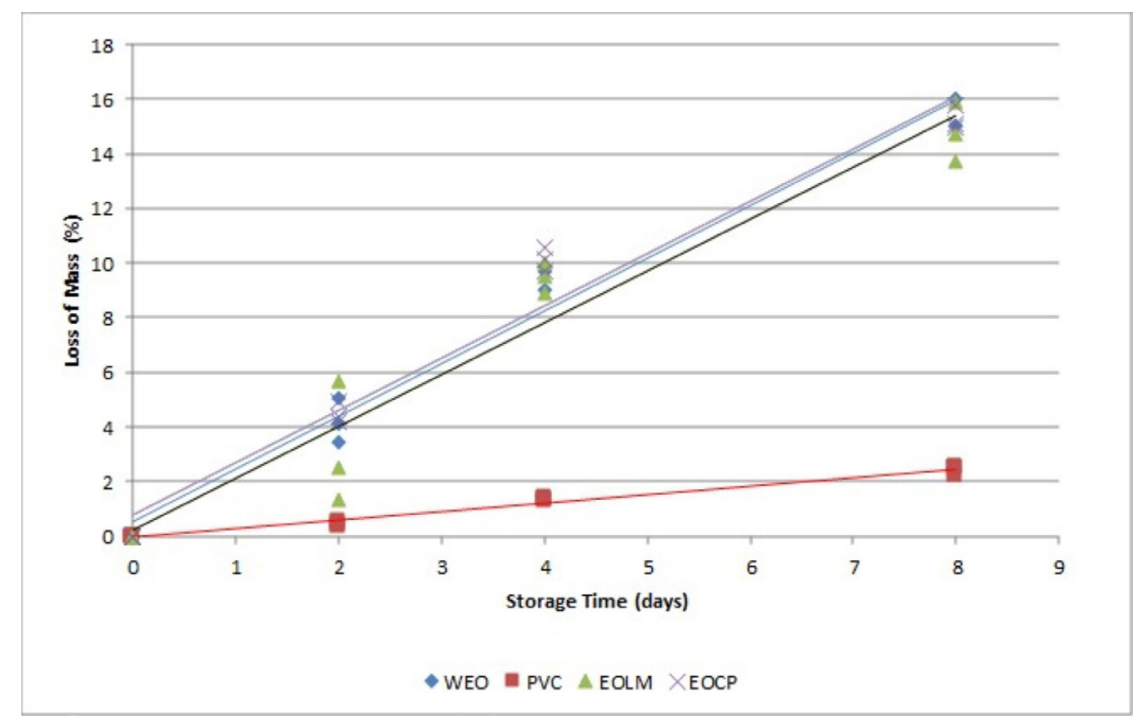

Figure 2: The loss of mass (LM) of minimally processed lettuce in relation to the protective film used in packaging (WEO: biodegradable film without essential oil, PVC: conventional film, EOLM: biodegradable film with essential oil of lemongrass, and EOCP: biodegradable film with essential oil of copaiba). 
in relation to the count at time zero $(p<0.05)$. The starch/ $\mathrm{PVOH} /$ alginate films with copaiba oil presented smaller mold and yeast counts than other treatments did at this time, indicating the addition of oils had an effect on the fungi present in microbial flora.

The mesophile count had increased significantly at the eighth day of storage for all treatments $(p<0.05)$. $\mathrm{PVC}$ films and starch/PVOH/alginate films without the addition of essential oil showed the lowest counts of total coliforms during storage. The films with EOCP or EOLM did not exercise control over the development of these microorganisms. The samples showed no count for fecal coliforms; these results indicate that the microbiological standards established for this microorganism were met during the storage period (Brasil, 2001). The starch/ $\mathrm{PVOH} /$ alginate films did not decrease the development of total coliforms, but at the same time, they did not contribute to the development of these microorganisms. The films with EOCP exercised protection in relation to molds and yeasts (Table 3), indicating that there was greater microbiological control in starch/PVOH/alginate films with essential oil.

\section{Physicochemical analysis}

The values of TSS, $\mathrm{pH}$, TTA, and ASC were determined for each treatment in the different storage times. These are presented in Figure 3.
The values of TSS varied according to the storage period in all treatments (Figure 3, F3-B). Soluble solids are simple sugars that can be used in the storage of lettuce in the processes of cellular respiration. The lettuce stored in PVC films exhibited a greater decrease in the TSS value after 2 days of storage; the value increased soon after this point, probably due to the degradation of sugars of cellular wall, resulting in an increase of TSS after 4 days of storage. The rapid decrease in the values of TSS at 2 days may have occurred due to the cutting process used for minimally processed foods, which increases the contact enzyme substrate and the speed of the biochemical reactions. The starch/PVOH/ alginate films with or without essential oil only showed a significant reduction in the value of TSS on the eighth day of storage $(p<0.05)$. The results suggested that the speed of oxidative reactions involved in respiration was greater in the lettuce packed with PVC.

The TTA of the lettuce leaves decreased significantly from the second day of storage for all treatments $(p<0.05)$, followed by a nonsignificant increase $(p>0.05)$ in the biodegradable films and continuous decline in the film with PVC (Figure 3, F3-A). The increase in $\mathrm{pH}$ values confirmed the decrease in acidity (Figure 3, F3-C). Such a decrease in acidity is related to the enzymatic reactions that occur in minimally processed food. Mattos et al. (2007) found the same behavior in minimally processed lettuce.

Table 3: Microbiological stability of minimally processed lettuce stored in different containers under chilled conditions.

\begin{tabular}{|c|c|c|c|c|c|}
\hline \multirow{2}{*}{ Treatment } & \multirow{2}{*}{ Time (days) } & \multicolumn{3}{|c|}{ Count (UFC/g) } & \multirow[b]{2}{*}{ Fecal Coliforms } \\
\hline & & Molds and yeasts & Mesophile & Total coliforms & \\
\hline WEO & \multirow{4}{*}{0} & $1.8 \times 10^{4 \mathrm{~b}, \mathrm{~A}}$ & $1.60 \times 10^{5 \mathrm{~b}, \mathrm{~A}}$ & $1.27 \times 10^{5 \mathrm{a}, \mathrm{A}}$ & 0 \\
\hline PVC & & $1.8 \times 10^{4 \mathrm{~b}, \mathrm{~A}}$ & $1.60 \times 10^{5 \mathrm{~b}, \mathrm{~A}}$ & $1.27 \times 10^{5 \mathrm{a}, \mathrm{A}}$ & 0 \\
\hline EOLM & & $1.8 \times 10^{4 \mathrm{~b}, \mathrm{~A}}$ & $1.60 \times 10^{5 \mathrm{~b}, \mathrm{~A}}$ & $1.27 \times 10^{5 \mathrm{~b}, \mathrm{~A}}$ & 0 \\
\hline EOCP & & $1.8 \times 10^{4 \mathrm{~b}, \mathrm{~A}}$ & $1.60 \times 10^{5 \mathrm{~b}, \mathrm{~A}}$ & $1.27 \times 10^{5 \mathrm{~b}, \mathrm{~A}}$ & 0 \\
\hline WEO & \multirow{4}{*}{2} & $2.15 \times 10^{5 \mathrm{~b}, \mathrm{~A}}$ & $2.2 \times 10^{6 \mathrm{~b}, \mathrm{~B}}$ & $1.65 \times 10^{5 a, B}$ & 0 \\
\hline PVC & & $3.50 \times 10^{4 \mathrm{~b}, \mathrm{~A}}$ & $1.50 \times 10^{6 \mathrm{~b}, \mathrm{~B}}$ & $5.40 \times 10^{5 a, B}$ & 0 \\
\hline EOLM & & $1.00 \times 10^{5 \mathrm{~b}, \mathrm{~A}}$ & $1.00 \times 10^{7 \mathrm{~b}, \mathrm{~A}}$ & $5.60 \times 10^{6} \mathrm{~b}, \mathrm{~A}$ & 0 \\
\hline EOCP & & $4.00 \times 10^{4 b, B}$ & $1.12 \times 10^{7 \mathrm{a}, \mathrm{A}}$ & $7.60 \times 10^{6 \mathrm{~b}, \mathrm{~A}}$ & 0 \\
\hline WEO & \multirow{4}{*}{8} & $1.8 \times 10^{7 \mathrm{a}, \mathrm{A}}$ & $2.98 \times 10^{8} \mathrm{a}, \mathrm{A}$ & $3.50 \times 10^{6} \mathrm{a}, \mathrm{c}$ & 0 \\
\hline PVC & & $1.5 \times 10^{7, a, A}$ & $8.80 \times 10^{7} \mathrm{a}, \mathrm{AB}$ & $1.65 \times 10^{5} \mathrm{a}, \mathrm{c}$ & 0 \\
\hline EOLM & & $1.5 \times 10^{7 \mathrm{a}, \mathrm{A}}$ & $1.00 \times 10^{7 \mathrm{a}, \mathrm{B}}$ & $2.40 \times 10^{7} \mathrm{a}, \mathrm{B}$ & 0 \\
\hline EOCP & & $4.5 \times 10^{6} \mathrm{a}, \mathrm{B}$ & $1.12 \times 10^{7 \mathrm{a}, \mathrm{B}}$ & $4.15 \times 10^{7} \mathrm{a}, \mathrm{A}$ & 0 \\
\hline
\end{tabular}

Values followed by the same letter were not significantly different according to the Tukey test at 95\% probability. Lowercase letters compare the same treatment at different times, and upper case letters compare different treatments at the same time. 

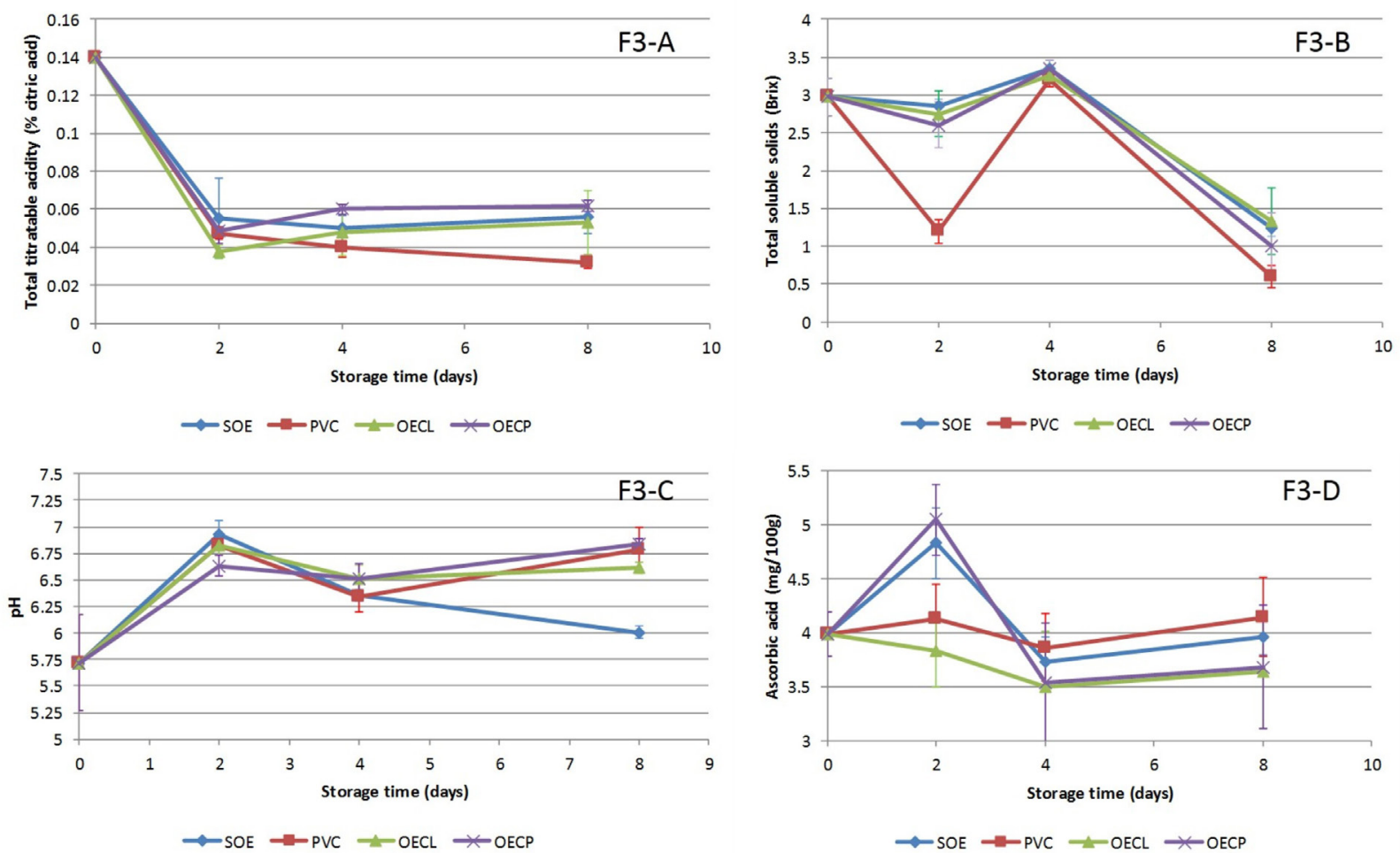

Figure 3: Behavior of the values of total titratable acidity (TTA; F3-A), total soluble solids (TSS; F3-B), pH (F3-C), and ascorbic acid content (Ascorbic; F3-D) for minimally processed lettuce and packed in films without essential oil (WEO), films of PVC (PVC), films with oil of lemongrass (EOLM), and films with copaiba oil (EOCP). The averages were analyzed using Tukey's test $(p=0.05)$.

The values of the ASC were determined for the lettuce packed in different treatments (Figure 3, F3-D). It was observed that there were no significant differences in the values during storage with exception of the WEO films, which presented an increase in value to 2 days of storage. The values of ASC determined at 8 days equaled the levels analyzed at time zero in all treatments $(p>0.05)$. Marin et al. (2010) observed $50 \%$ of increase in the values of ASC in lettuce stored in pure starch films; according to these authors, the effect should be device an excessive loss mass (40\%), which caused a concentration of vitamins. LMs were also determined in this work, but the values were minor (close to 16\%), and no effect was exerted on the evaluated physicochemical parameters.

\section{Analysis of color}

The color parameters $-\mathrm{a}^{*}, \mathrm{~b}^{*}, \mathrm{C}^{*}$, and $\mathrm{L}^{*}$ for lettuce stored in each starch/PVOH/alginate film with or without essential oil and PVC films were determined. These are presented in Figure 4.
The lettuce leaves were characterized by yellowgreen coloration. The leaves of lettuce stored in EOLM films best preserved the green-yellow coloration observed at time zero throughout the storage period. Positive values of " $b$ " indicates the yellow coloration, and negative values of parameter " $\mathrm{a}$ *" indicate greater green coloration. As shown in Figure 4, the $-\mathrm{a}^{*}$ and $\mathrm{b}$ parameters various to treatments differed after 2 days of storage $(p<0.05)$. The lettuce showed a tendency to diminish the green color with the storage time in the WEO and EOCP films. The lettuce in EOLM films and PVC films did not change parameter $-a^{*}$ during storage. Parameter $b^{*}$ changed during of storage. The leaves of lettuce storage in WEO and EOCP films exhibited a decrease in yellow color.

The decrease in green color was related to the degradation of chlorophyll, which is sensitive to oxygen among other factors; when chlorophyll is degraded by the action of oxygen, colorless compounds are formed, and the green color is attenuated. These results indicate that the starch films with EO of lemongrass and PVC films probably presented a greater barrier to the permeation 
of oxygen to the interior of the packaging than starch/ $\mathrm{PVOH} /$ alginate films without oil and films incorporating with EOCP. The yellow color represents the amount of carotenes, which are also sensitive to the action of oxygen gas. The EOLM and PVC films resulted in a minor loss of color during at storage time (Figure 4).

The phenol contents in minimally processed lettuce leaves may be oxidized, resulting in dark pigments; this process is known as enzymatic browning (Soliva-Fortuny; Martín-Belloso, 2003). The occurrence of enzymatic browning can diminish lightness $\left(\mathrm{L}^{*}\right)$, and it can be increase the gray tones, consequently increase the values of $C^{*}$ (Mattos et al., 2007). It was observed that there was an increase in the values of $\mathrm{L}^{*}$ for the treatments with biodegradable films and a decrease for the PVC treatment at 4 days of storage; at this stage, the values of $\mathrm{C}^{*}$ had already increased in the lettuce packaged in films with PVC, remained the same in EOLM films, and declined in EOCP and WEO films. Mattos et al. (2007) found that minimally processed lettuce presented a lower
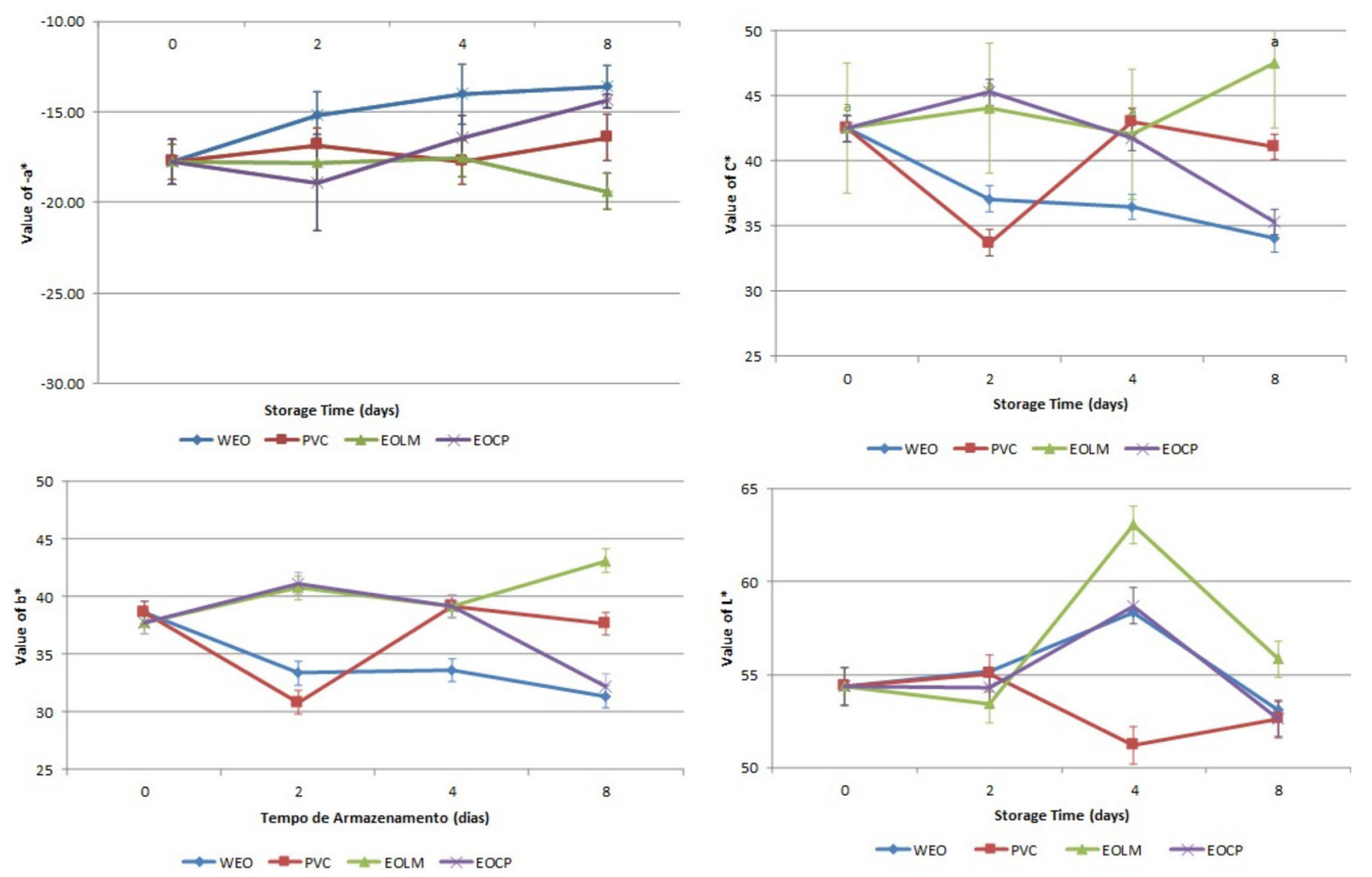

Figure 4: Parameters of color $\left(-a^{*}, b^{*}, L^{*}\right.$, and $\left.C^{*}\right)$ analyzed from minimally processed lettuce throughout the storage period.

lightness value than lettuce in whole leaves. These authors concluded that the higher activity of peroxidase and polyphenol oxidase in cut leaves was responsible for the results. In comparison with the results of these authors, the findings of this study suggest a greater barrier to oxygen in starch/PVOH/alginate films added of lemongrass oil, resulting in protection of the phenolic compounds.

\section{Multivariate analysis}

Multivariate statistical analysis was applied to the variables analyzed to distinguish the effects of the treatment. In the dendrogram in Figure 5 (F5-A), four groups (or clusters) of different treatments can be observed at $p<0.05$. The samples from time zero (WEO0, PVC0, EOLM0 and EOCP) and WEO lettuce stored for 2 days (WEO2) formed the first group of samples. The second group was formed by the treatments with essential oil at 2 and 4 days of storage and by treatment with PVC film at 4 and 8 days of storage (PVC4 and PVC8). The third group was formed by the treatments of films without essential 

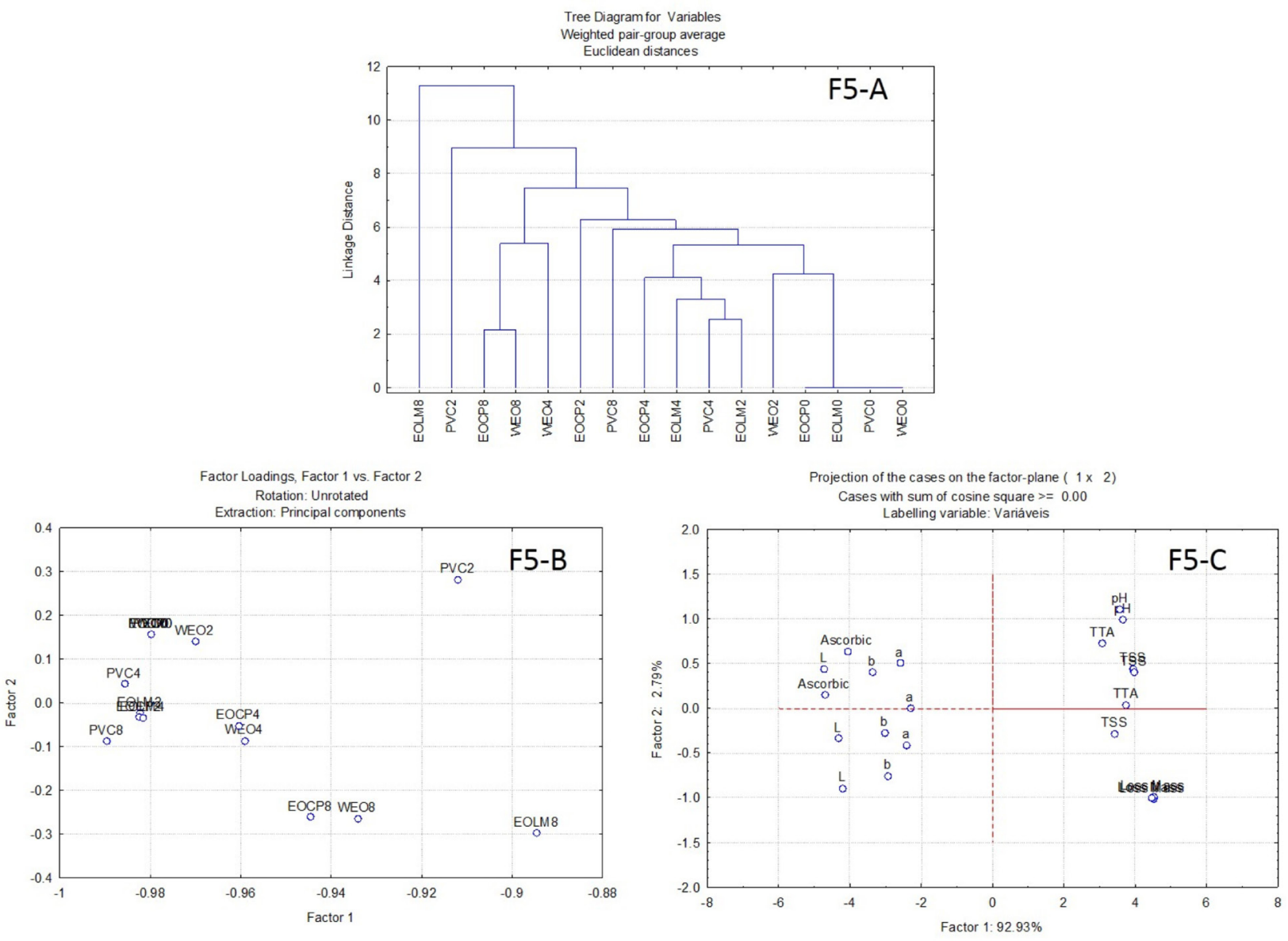

Figure 5: Multivariate analysis applied to the study of biofilms in minimally processed lettuce storage.

oil at 4 and 8 days (WEO4, WEO8) and by treatment with EOCP at 8 days (EOCP8). The treatments that were most different from the samples at time zero were those with essential oil of lemongrass at 8 days of storage (EOLM8), followed by PVC2 (samples in PVC with 2 days of storage), which formed the fourth group. In this way, the treatments in the third and fourth groups were the most different in relation to the lettuce leaves at time zero.

The analysis of the main components is represented by graphs of scores (Figure 5, F5-B) and the loadings (Figure 5, F5-C); the joint analysis of both graphics allow which of the analyzed variables were important to explain the difference between the treatments to be observed. The lettuce samples packed with starch/PVOH/alginate films with or without EO for 8 days of storage differed from treatments PVC due to LM, being that the mass loss was not an important factor to distinguish the biodegradable films at 8 and at 4 and 2 days of storage (Figure 5, F5-B and F5-C). The treatment of PVC2 films differed from the others due to the physicochemical parameters (TSS, TTA, pH). The biodegradable films and PVC films at 4 and 8 days were similar due to the color parameters and amounts of ascorbic acid.

The graph of scores (Figure 5, F5-C) indicates that the scores for treatment in biodegradable films with essential oil at 0,2 , and 4 days of storage were alike; thus, it is considered that these groups were similar to each other. The high LM of lettuce leaves packaged in biodegradable films limited the maximum time of storage to 4 days. PVC films allowed greater loss in TSS at 2 days of storage, compromising the quality of leaves, as discussed above.

\section{CONCLUSIONS}

Starch/PVOH/alginate films with or without essential oil did not contributed to the increase in the microorganism contents of lettuce. The LM was the main parameter for differentiation of lettuce stored in 
biodegradable films compared to that packed in PVC, as the PVC film was more efficient in the control of LM. The addition of EO did not improve the biofilms' ability to serve as a barrier against water vapor. The analysis of TSS indicated that the PVC films were not efficient in maintaining the quality of lettuce from about 2 days of storage. The color analysis indicated that EOLM films were more efficient in protecting the color than the PVC films. The multivariate analysis also showed that lettuce stored in biofilms with EO for 4 days and without EO for 2 days were considered more similar to the other treatments at time zero. The starch/PVOH/alginate biofilms were considered to be viable in the storage of minimally processed lettuce for up to 4 days and may replace PVC packaging in the studied conditions.

\section{ACKNOWLEDGMENTS}

The authors are grateful for the financial support and the F. M. De Almeida scholarship provided by the Federal University of Technology - Paraná.

\section{REFERENCES}

AMERICAN SOCIETY FOR TESTING AND MATERIALS (ASTM). Standard test methods for water vapor transmission of material - E 96-95. In: Annual book of ASTM standards. Philadelphia: ASTM. 1995. p.1-8

AMERICAN SOCIETY FOR TESTING AND MATERIALS (ASTM). Standard test methods for tensile properties of thin plastic sheeting - D 882-02. In: Annual book of ASTM standards. Philadelphia: ASTM. 1996. p.1-10.

BENASSI, M. T.; ANTUNES, A. J. A comparison of metaphosphoric and oxalic acids as extracts solutions for the determination of vitamin C in selected vegetables. Brazilian Archives of Biology and Technology, 31(4):507-513, 1988.

BERGO, P. V. A. et al. Physical properties of edible films based on cassava starch as affected by the plasticizer concentration. Packaging Technology Science. 21:8589, 2008.

BRANDELERO, R. P. H.; GROSSMANN, M. V. E.; YAMASHITA, F. The effect of surfactant Tween 80 on the hydrophilicity, water vapor permeation, and the mechanical properties of cassava starch and poly(butylene adipate-co-terephthalate) (PBAT) blend films. Carbohydrate Polymers. 82:11021109, 2010.

BRANDELERO, R. P. H. et al. Mixture design applied to evaluating the effects of polyvinyl alcohol $(\mathrm{PVOH})$ and alginate on the properties of starch-based films. Starch/ Stärke. 66:1-9, 2014.

BRASIL. Agência Nacional de Vigilância Sanitária. Resolução (ANVISA) - RDC n. 12, de 02 de janeiro de 2001 - Aprova o Regulamento Técnico sobre padrões microbiológicos para alimentos. Diário Oficial da União. Brasília, 10 de janeiro de 2001. Seção 1.

BRASIL. Ministério Da Agricultura, Pecuária E Abastecimento. Secretaria de Defesa Agropecuária (DISPOA). Instrução Normativa n. 62, de 26 de agosto de 2003. Oficializa os Métodos Analíticos Oficiais para Análises Microbiológicas para Controle de Produtos de Origem Animal e Água. Diário Oficial da União. Brasília, 26 de agosto de 2003. xxxp.

BURT, S. Essential oils: Their antibacterial properties and potential applications in foods. A review. International Journal of Food Microbiological. 94(3):223-253, 2004.

CÓRDOBA, A. et al. The plasticizing effect of alginate on the thermoplastic starch/glycerin blends. Carbohydrate Polymer. 73:409, 2008.

DEBIAGI, F. et al. Biodegradable active packaging based on cassava bagasse, polyvinyl alcohol and essential oil. Industrial Crops and Products. 52:664-670, 2014.

FAKHOURI, F. M. et al. Filmes e coberturas comestíveis compostas à base de amidos nativos e gelatina na conservação e aceitação sensorial de uvas Crimson. Ciência e Tecnologia de Alimentos. 27(2):369-375, 2007.

FALGUERA, V. et al. Edible films and coatings: structures, active function and trends in their use. Trends in Food Science \& Technology. 22: 292-303, 2011.

GALLARDO-PÉREZ, A. et al. Effect of structural characteristics of modified waxy corn starches on rheological properties, film-forming solutions, and on water vapor permeability, solubility, and opacity of films. Starch/Stärke. 64:27-36, 2012.

GHASEMLOU, M. et al. Physical, mechanical and barrier properties of corn starch films incorporated with plant essential oils. Carbohydrate Polymer. 98:1117-1126, 2013.

GUILBERT, S.; GONTARD, N.; GORRIS, L. G. M. Prolongation of the shelf-life of perishable food products using biodegradable films and coatings. LebensmittelWissenschaft \& Technologie. 29:10-17, 1996.

GUIMARÃES, L. G. L. et al. Atividades antioxidante e fungitóxica do óleo essencial de capim-limão. Revista Ciência Agronômica. 42(2):464-472, 2011. 
INSTITUTO ADOLFO LUTZ. Métodos Químicos e Físicos para análise de alimentos. Normas Analíticas do Instituto Adolfo Lutz. São Paulo: IMESP, v.1, 1985. 288p.

KOIDE, S.; JOHN, S. Microbial and quality evaluation of green peppers stored in biodegradable film packaging. Food Control. 18:1121-1125, 2007.

LIN, D.; ZHAO, Y. Innovation in the development and application of edible coating for fresh and minimally processed fruits and vegetables. Comprehensive Reviews in Food Science and Food Safety. 6:60-75, 2007.

MALI, S. et al. Effects of controlled storage on thermal, mechanical and barrier properties of plasticized films from different starch sources. Journal of Food Engineering. 75:453-460, 2006.

MALI, S.; GROSSMANN, M. V. E.; YAMASHITA, F. Filmes de amido: Produção, propriedades e potencial de utilização. Semina: Ciências Agrárias. 31(1):137-156, 2010.

MARIN, T. et al. Embalagem ativa para alface americana (Lactuca sativa L.) minimamente processada. Semina: Ciências Agrárias. 31(3):653-660, 2010.
MATTOS, L. M. et al. Qualidade de alface crespa minimamente processada armazenada sob refrigeração em dois sistemas de embalagem. Horticultura Brasileira. 25:504-508, 2007.

PELISSARI, F. M. et al. Antimicrobial, mechanical and barrier properties of cassava starch-chitosan films incorporated with oregano essential oil. Journal of Agriculture and Food Chemistry. 57:7499- 7504, 2009.

PIERI, F. A.; MUSSI, M. C.; MOREIRA, M. A. S. Óleo de copaíba (Copaifera sp.): Histórico, extração, aplicações industriais e propriedades medicinais. Revista Brasileira de Plantas Medicinais. 11(4):465-472, 2009.

SOLIVA-FORTUNY, R. C.; MARTÍN-BELLOSO, O. New advances in extending the shelf-life of fresh-cut fruit. A review. Trends in Food Science \& Technology. 14:341-353, 2003.

SOUZA, A. C. et al. Cassava starch composite films incorporated with cinnamon essential oil: Antimicrobial activity, microstructure, mechanical and barrier properties. LWT Food Science and Technology. 54:346-352, 2013.

TALJA, R. A. et al. Effect of type and content of binary polyol mixtures on physical and mechanical properties of starch-based edible films. Carbohydrate Polymers. 71:269-276, 2008. 